\title{
Long-term sensitization training in Aplysia decreases the excitability of a decision-making neuron through a sodium-dependent mechanism
}

\author{
John S. Hernandez, ${ }^{1,2}$ Marcy L. Wainwright, ${ }^{1}$ and Riccardo Mozzachiodi ${ }^{1}$ \\ ${ }^{1}$ Department of Life Sciences, Texas A\&M University - Corpus Christi, Corpus Christi, Texas 78412, USA
}

\begin{abstract}
In Aplysia, long-term sensitization (LTS) occurs concurrently with a suppression of feeding. At the cellular level, the suppression of feeding is accompanied by decreased excitability of decision-making neuron B51. We examined the contribution of voltage-gated $\mathrm{Na}^{+}$and $\mathrm{K}^{+}$channels to $\mathrm{B} 51$ decreased excitability. In a pharmacologically isolated $\mathrm{Na}^{+}$channels environment, LTS training significantly increased B51 firing threshold, compared with untrained controls. Conversely, in a pharmacologically isolated $\mathrm{K}^{+}$channels environment, no differences were observed between trained and untrained animals in either amplitude or area of $\mathrm{B}^{5} \mathrm{~K}^{+}$-dependent depolarizations. These findings suggest that $\mathrm{Na}^{+}$channels contribute to the decrease in B51 excitability induced by LTS training.
\end{abstract}

[Supplemental material is available for this article.]

The mechanisms by which aversive stimuli modulate the activity of defensive neural circuits have been extensively studied in vertebrates and invertebrates (e.g., Frost et al. 1985; Kandel 2001; Tomchik and David 2009; Ardiel and Rankin 2010; Johansen et al., 2011; LeDoux 2012; Byrne and Hawkins 2015). Conversely, the effects of aversive stimuli on nondefensive neural circuits have been only marginally explored. In Aplysia, aversive electrical stimuli, which mimic a predator attack (Watkins et al. 2010; Mason et al. 2014), induce concurrent sensitization of withdrawal reflexes (e.g., Frost et al. 1985; Cleary et al. 1995; Kandel 2001; Byrne and Hawkins 2015) and suppression of feeding (Acheampong et al. 2012; Shields-Johnson et al. 2013). Despite the extensive knowledge of the mechanisms of sensitization (e.g., Scholz and Byrne 1987; Cleary et al. 1998; Wainwright et al. 2002; Herdegen et al. 2014), only recently have we begun to investigate the cellular underpinnings responsible for the suppression of feeding (Shields-Johnson et al. 2013).

In Aplysia, a 1-day training protocol, which induces longterm sensitization (LTS) of the tail-elicited siphon withdrawal reflex (TSWR), also suppresses feeding for at least $24 \mathrm{~h}$ (Acheampong et al. 2012; Shields-Johnson et al. 2013). A cellular correlate of feeding suppression is the decreased excitability of a putative decision-making neuron within the feeding central patter generator (CPG): neuron B51 (Shields-Johnson et al. 2013). B51 generates an all-or-nothing intrinsic burst of action potentials (i.e., plateau potential) (Plummer and Kirk 1990) that contributes to the selection of ingestive buccal motor programs (BMPs), which are in vitro neurophysiological correlates of biting (Nargeot et al. 1999a,b; Brembs et al. 2002; Nargeot and Simmers 2012). Modifications of B51 excitability have been previously associated with changes in feeding induced by nonassociative (ShieldsJohnson et al. 2013) and associative forms of learning (Brembs et al. 2002; Lorenzetti et al. 2006) as well as by food satiation (Dickinson et al. 2015).

\footnotetext{
2Present address: Neuroscience and Behavior Program, University of Massachusetts, Amherst, MA 01003, USA.

Corresponding author: riccardo.mozzachiodi@tamucc.edu

Article is online at http://www.learnmem.org/cgi/doi/10.1101//m.044883. 116.
}

The decrease of B51 excitability, measured $24 \mathrm{~h}$ after LTS training, manifests as an increase in the amount of current necessary to drive B51 into producing its plateau potential (i.e., burst threshold) (Nargeot et al. 1999a; Shields-Johnson et al. 2013). Resting membrane potential $\left(V_{\mathrm{m}}\right)$ and input resistance $\left(R_{\mathrm{m}}\right)$ are not affected by LTS training (Shields-Johnson et al. 2013). Previous work revealed that B51 plateau potential does not depend on external $\mathrm{Ca}^{2+}$ (Plummer and Kirk 1990), suggesting that voltage-gated (VG) $\mathrm{Na}^{+}$and $\mathrm{K}^{+}$currents are involved in its genesis and maintenance. Therefore, the goal of this study was to identify biophysical changes underlying B51 decreased excitability following LTS training.

To assess learning-induced behavioral modifications, the TSWR and feeding were measured prior to (pre-test) and $24 \mathrm{~h}$ after (post-test) treatment (LTS training/no training) (Acheampong et al. 2012; Shields-Johnson et al. 2013; Supplemental Fig. 1A; see also Supplemental Material for details about testing and training procedures). The duration of the siphon withdrawal was used as a measure of the TSWR strength (Scholz and Byrne 1987; Cleary et al. 1998). The number of bites (i.e., rhythmic movements of the radula) (Kupfermann 1974; Susswein et al. 1976), counted during a 5-min test, was used to assess feeding (Brembs et al. 2002; Acheampong et al. 2012). The experimenter performing the behavioral tests was unaware of the treatment history of the animals. Training induced concurrent LTS (change in TSWR duration, trained: $1.7 \pm 0.1, n=30$; untrained: $1.2 \pm 0.2, n=33 ; P<$ 0.05; $U=188.5$; Mann-Whitney $U$-test; Fig. 1A) and suppression of feeding (difference in bites; trained: $-7.9 \pm 1.1, n=34$; untrained: $1.1 \pm 1.2, n=43 ; P<0.05 ; U=263.5$; Mann-Whitney $U$-test; Fig. 1B).

Once behavioral post-tests were completed, the buccal ganglia were removed and B51 properties were measured in artificial seawater (ASW) (Supplemental Fig. 1B; see also Supplemental

(C) 2017 Hernandez et al. This article is distributed exclusively by Cold Spring Harbor Laboratory Press for the first 12 months after the full-issue publication date (see http://learnmem.cshlp.org/site/misc/terms.xhtml). After 12 months, it is available under a Creative Commons License (AttributionNonCommercial 4.0 International), as described at http://creativecommons. org/licenses/by-nc/4.0/. 
A

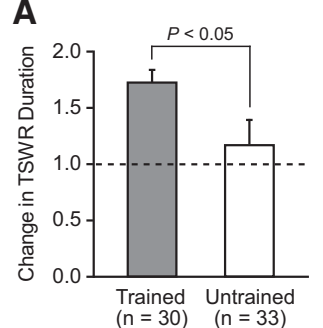

B
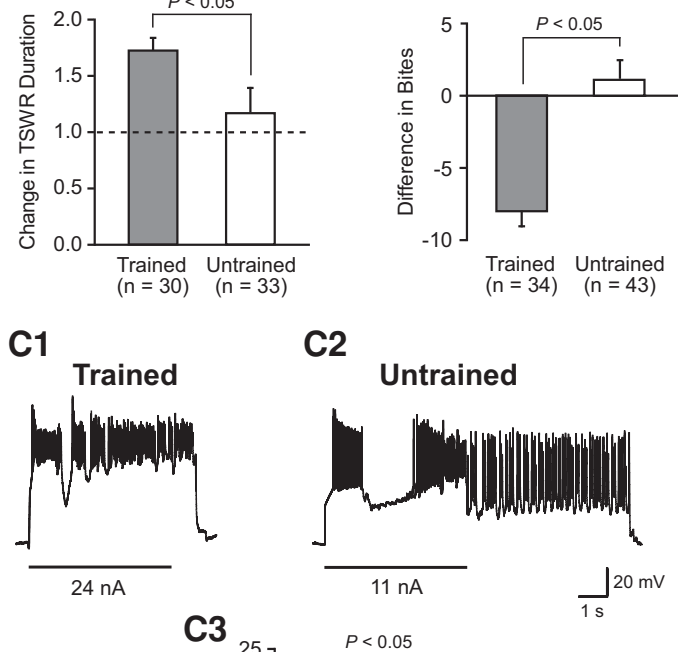

C2

Untrained
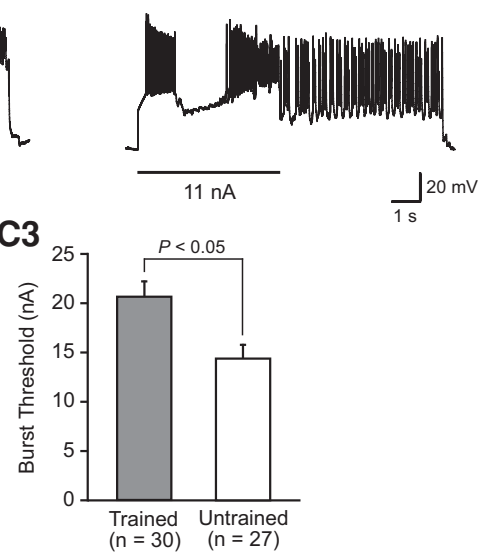

Figure 1. Training induced LTS of the TSWR, suppressed feeding and decreased the excitability of neuron B51. Training produced concomitant LTS $(A)$ and suppression of feeding (B) $24 \mathrm{~h}$ after training. (C) LTS Training also increased B51 burst threshold, resulting in decreased excitability $24 \mathrm{~h}$ after training. Sample traces of B51 from trained (C1) and untrained animals (C2) illustrate qualitative differences in burst threshold. (C3) Summary data illustrate that LTS training significantly increased B51 burst threshold. In these and the following figures, values are expressed as mean \pm SEM and statistical significance is set at $P<0.05$.

Material for details about the electrophysiological measurements). $V_{\mathrm{m}}$ was initially measured and, then, B51 was clamped at $-60 \mathrm{mV}$ to assess $R_{\mathrm{m}}$ and burst threshold (Nargeot et al. 1999a,b; Mozzachiodi et al. 2008). Confirming previous findings (Shields-Johnson et al. 2013), trained animals displayed a burst threshold significantly higher $(20.6 \pm 1.5 \mathrm{nA}, n=30$; Fig. $1 \mathrm{C} 1, \mathrm{C} 3)$ than untrained animals $(14.4 \pm 1.4 \mathrm{nA}, n=27 ; P<$ 0.05; $U=229.5$; Mann-Whitney $U$-test; Fig. 1C2,C3). Training did not modify either $V_{\mathrm{m}}$ (trained: $-54.9 \pm 0.9 \mathrm{mV}, n=30$; untrained: $-54.9 \pm 1.0 \mathrm{mV}, n=27 ; P=0.92 ; U=398.0$; MannWhitney $U$-test) or $R_{\mathrm{m}}$ (trained: $2.4 \pm 0.1 \mathrm{M} \Omega, n=29$; untrained: $2.5 \pm 0.1 \mathrm{M} \Omega, \quad n=27 ; \quad P=0.29 ; \quad U=327.0 ; \quad$ Mann-Whitney $U$-test). These results indicate that the expected decrease of B51 excitability occurred in a cohort of animals that exhibited concurrent LTS and feeding suppression, thus allowing us to explore its biophysical mechanisms.

Following the measurement of B51 properties in ASW, preparations from both trained and untrained animals were randomly assigned to one of two pharmacological environments in which selective channel blockers allowed us to isolate voltage responses of $\mathrm{VG} \mathrm{Na}^{+}$or $\mathrm{K}^{+}$channels to injected current (Dong et al. 2006; see below for details about channel blockers; Supplemental Fig. 1C1,C2). Ideally, B51 biophysical properties should be measured using voltage clamp. However, previous evidence indicates that voltage clamp in molluscan neurons, exhibiting morphology analogous to that of B51 (Weiss et al. 1986; Plummer and Kirk 1990; Staras et al. 2002) and expressing fast-inactivating $\mathrm{Na}^{+}$ channels (e.g., Gilly et al. 1997; Chen et al. 2012), required in situ manipulations, such as axotomy, to ensure adequate space clamp (e.g., Weiss et al. 1986; Staras et al. 2002; Nikitin et al. 2008). This approach could not be included in our experimental design that aimed to examine cell-wide learning-induced changes in VG-channel function (see Supplemental Material for additional details). Consequently, we used the current-clamp technique with pharmacological approaches to analyze the individual contribution of $\mathrm{VG} \mathrm{Na}{ }^{+}$and $\mathrm{VG} \mathrm{K}^{+}$channels to the training-induced decrease of B51 excitability (e.g., Dong et al. 2006; Supplemental Fig. 1C1,C2). The different combinations of channel blockers were bath applied as boluses directly to the buccal ganglia (see below for details).

To isolate $\mathrm{VG} \mathrm{Na}{ }^{+}$channels, $25 \mathrm{mM}$ tetraethylammonium (TEA) (Trudeau et al. 1993; Jacklet et al. 2006) and 4 mM 4-aminopyridine (4-AP) (Trudeau et al. 1993) were used to block delayed-rectifier and transient $\mathrm{VG} \mathrm{K}^{+}$channels, respectively. In addition, $15 \mathrm{mM} \mathrm{Co}^{2+}$ was used to block VG Ca ${ }^{2+}$ channels and $\mathrm{Ca}^{2+}$-dependent $\mathrm{K}^{+}$channels (Jacklet and Tieman 2004; Jacklet et al. 2006). Ten minutes after the application of the channel blockers, $V_{\mathrm{m}}$ of trained animals $(-49.9 \pm 1.8 \mathrm{mV}, n=10)$ were not significantly different from those of untrained animals $(-52.3 \pm 1.9 \mathrm{mV}, n=7 ; P=0.26 ; \quad U=23.0 ;$ Mann-Whitney $U$-test). B51 was then clamped at $-60 \mathrm{mV}$ to measure $\mathrm{Rm}$ and burst threshold. $R_{\mathrm{m}}$ of trained animals $(2.7 \pm 0.2 \mathrm{M} \Omega, n=9)$ were not significantly different from those of untrained animals (3.6 $\pm 0.7 \mathrm{M} \Omega, n=6 ; P=0.32 ; U=18.0 ;$ Mann-Whitney $U$-test).

In this pharmacological environment, B51 was able to fire a discharge of action potentials in response to current injections, but did not plateau (see Supplemental Material for details). Although B51 plateau potential does not depend on $\mathrm{Ca}^{2+}$ and can still be elicited in the presence of $\mathrm{Co}^{2+}$ (Plummer and Kirk 1990), it was disrupted with the addition of 4-AP and TEA (Fig. $2 \mathrm{~A} 1, \mathrm{~A} 2)$, suggesting that delayed-rectifier $\mathrm{K}^{+}$channels and/or transient $\mathrm{K}^{+}$channels may contribute to its expression. A similar

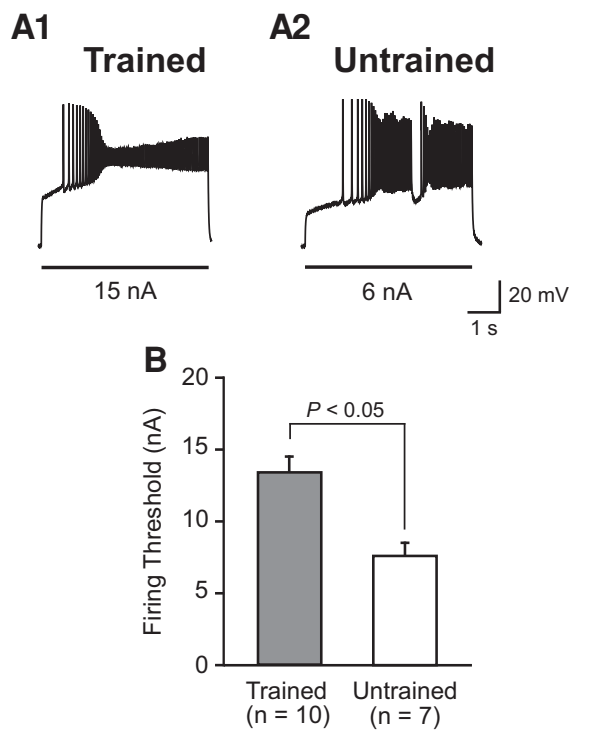

Figure 2. LTS training selectively modified the $\mathrm{Na}^{+}$-dependent firing threshold of neuron B51. Sample traces of B51 from trained (A1) and untrained animals $(A 2)$ illustrate qualitative differences in firing thresholds in the pharmacological environment in which $\mathrm{VG} \mathrm{Na}{ }^{+}$channels were isolated. The intensity of the injected current in the isolated $\mathrm{VG} \mathrm{Na}^{+}$channels environment indicates the threshold at which B51 fired action potential (i.e., firing threshold; $A 1, A 2$ ). (B) Summary data illustrate that LTS training significantly increased B51 firing threshold. 
scenario has been reported in B31/32 where delayed rectifier and transient $\mathrm{A} \mathrm{K}^{+}$channels participate to the sustained depolarization underlying the plateau potential (Hurwitz et al. 2008). In light of this finding, the firing threshold (i.e., the minimum amount of current necessary to elicit action potentials) was used in lieu of the burst threshold to assess B51 excitability. Mirroring the burst-threshold results obtained in ASW (Fig. 1), trained animals exhibited a firing threshold $(13.4 \pm 1.1 \mathrm{nA}, n=10$; Fig. $2 \mathrm{~A} 1, \mathrm{~B})$ greater than that of untrained animals $(7.6 \pm 0.8 \mathrm{nA}, n=$ $7 ; P<0.05 ; U=4.5$; Mann-Whitney $U$-test; Fig. $2 \mathrm{~A} 2$,B). This finding indicates that the training-induced decrease of B51 excitability observed in ASW persisted in the absence of contributions of $\mathrm{K}^{+}$or $\mathrm{Ca}^{2+}$ channels, suggesting that long-term modifications altered the properties (activation and/or conductance) of VG $\mathrm{Na}^{+}$channels.

To isolate VG $\mathrm{K}^{+}$channels, $100 \mu \mathrm{M}$ tetrodotoxin (TTX) (Trudeau et al. 1993; Dong et al. 2006; Chen et al. 2012) was used to block VG Na${ }^{+}$channels, along with $15 \mathrm{mM} \mathrm{Co}^{2+}$. Ten minutes after channel blockers application, $V_{\mathrm{m}}$ of trained $(-50.1 \pm$ $1.9 \mathrm{mV}, n=9)$ and untrained animals $(-52.9 \pm 1.8 \mathrm{mV}, n=10)$ were not significantly different $(P=0.32$; $U=32.5$; MannWhitney $U$-test). B51 was then clamped at $-60 \mathrm{mV}$ for the remaining measurements. As for $V_{\mathrm{m}}, R_{\mathrm{m}}$ were not significantly different between trained $(3.9 \pm 0.4 \mathrm{M} \Omega, n=7)$ and untrained animals $(3.6 \pm 0.5 \mathrm{M} \Omega, \quad n=10 ; \quad P=0.31 ; \quad U=24.0$; MannWhitney $U$-test). In this pharmacological environment, action potentials were no longer evoked in B51. Consequently, together with $V_{\mathrm{m}}$ and $R_{\mathrm{m}}$, we measured the amplitude and area of $\mathrm{K}^{+}$-dependent depolarizations, evoked by 5 -sec depolarizing pulses of incremental intensities from 5 to $30 \mathrm{nA}$, corresponding to the range in which B51 plateau potentials are generated in ASW (Shields-Johnson et al. 2013; Dickinson et al. 2015). For each depolarization, the peak amplitude and the area were measured (Supplemental Fig. 2; Shields-Johnson et al. 2013). The peak amplitudes of the depolarizations evoked in the 5-30 nA range were not significantly different between trained $(n=8)$ and untrained $(n=9)$ animals $\left(F_{(1,25)}=0.17 ; P=0.69\right.$; repeated-measures ANOVA on the factor "training"; Fig. 3A). Similarly, the areas of the depolarizations were not significantly different between trained $(n=8)$ and untrained $(n=9)$ animals $\left(F_{(1,25)}=0.02 ; P=\right.$ 0.89 ; repeated-measures ANOVA on the factor "training"; Fig. 3B).

Overall, the above results indicate that the decrease of B51 excitability is due, at least in part, to a learning-induced modulation of $\mathrm{VG} \mathrm{Na} \mathrm{Na}^{+}$channels. Conversely, no differences were observed between trained and untrained animals in either amplitude or area of B51 depolarizations measured in a pharmacologically isolated $\mathrm{VG} \mathrm{K}^{+}$channels environment, suggesting that VG $\mathrm{K}^{+}$channels are not a target of LTS training.

The pharmacological environment utilized to isolate the contribution of $\mathrm{VG} \mathrm{Na}{ }^{+}$channels and the current-clamp technique used to record the neuron's voltage responses cannot help fully describe the biophysical properties of the $\mathrm{Na}^{+}$currents involved in the decrease of excitability. However, our findings indicate that B51 action potentials are sustained by fast-inactivating $\mathrm{Na}^{+}$channels that are sensitive to TTX (Supplemental Fig. 2), confirming voltage-clamp data previously obtained from B51 in culture (Chen et al. 2012). A possible TTX-insensitive persistent $\mathrm{Na}^{+}$current might contribute to the depolarization supposedly carried primarily by $\mathrm{K}^{+}$ions. Nevertheless, we did not observe any change in the curves of peak amplitude and area of the depolarizations, indicating that LTS training did not alter them, regardless of their composition: either $\mathrm{K}^{+}$channels, or a combination of $\mathrm{K}^{+}$channels and TTX-resistant $\mathrm{Na}^{+}$channels. The possibility that the lack of learning-induced changes in depolarization might be due to opposite changes in $\mathrm{K}^{+}$currents and TTX-resistant $\mathrm{Na}^{+}$currents cancelling each other is unlikely. In
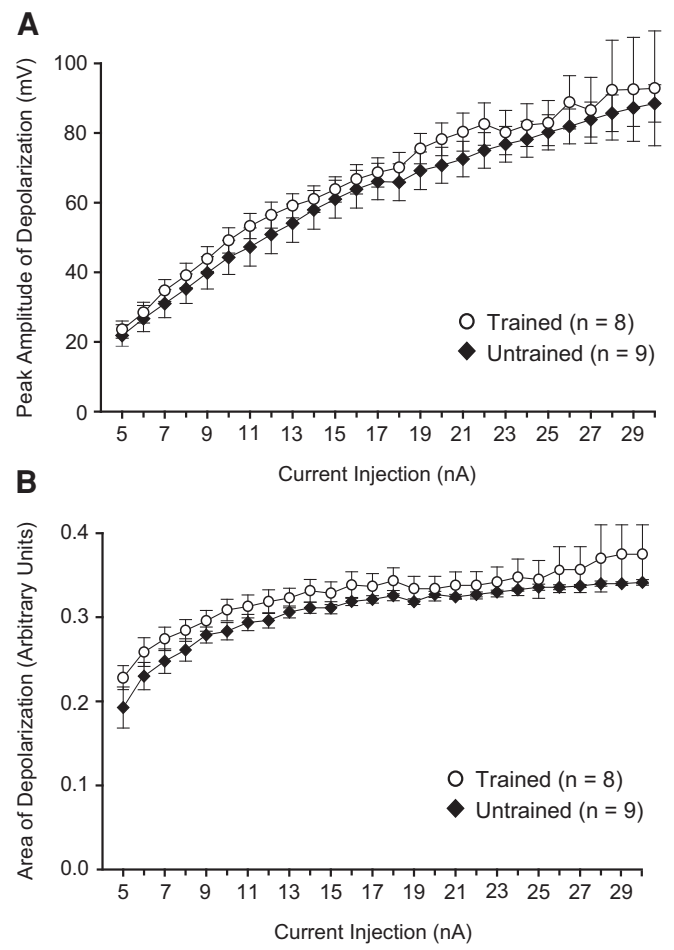

Figure 3. LTS training did not alter the peak amplitude or area of B51 depolarizations measured in the pharmacological environment in which $\mathrm{VG} \mathrm{K}^{+}$channels were isolated. (A) The peak amplitude curves of the depolarizations evoked in B51 in the 5-30 nA range did not differ between trained and untrained animals. (B) Similarly, the area curves of the depolarizations evoked in B51 in the 5-30 nA range did not differ between trained and untrained animals.

addition, learning-induced changes of persistent $\mathrm{Na}^{+}$currents have been associated with depolarizations of the resting membrane potential (Kemenes et al. 2006), a correlate that was not observed in B51 following LTS. Therefore, our results provide one of the first pieces of evidence describing learning-induced modifications in the function of $\mathrm{VG} \mathrm{Na}^{+}$channels in a behaviorally relevant decision-making neuron.

Research in the past decades has shown that modifications of excitability can contribute to the memory trace (e.g., Brons and Woody 1980; Crow and Alkon 1980; Nargeot et al. 1999a,b; Schall 2003; Zhang and Linden 2003; Mozzachiodi and Byrne 2010). Furthermore, work conducted on the mammalian hippocampus suggests that knockout of voltage-gated ion channels (e.g., HCN1) results in a robust change in behavioral output that promotes anxiolytic- and antidepressant-like behaviors (Lewis et al. 2011; Kim et al. 2012). Investigations on the biophysical substrates of behavior and memory have focused primarily on modifications of $\mathrm{K}^{+}, \mathrm{Ca}^{2+}$, or $\mathrm{Ca}^{2+}$-activated $\mathrm{K}^{+}$channels in both vertebrates (e.g., Remage-Healey et al. 2011; Lambertsen et al. 2012; Mirkovic et al. 2012; Truchet et al. 2012; Lovell et al. 2013) and invertebrates (e.g., Alkon et al. 1985; Scholz and Byrne 1987; Farley 1988; for review, see Brunelli et al. 1997; Mozzachiodi and Byrne 2010). However, $\mathrm{Na}^{+}$channels have also become prime candidates for a role in mediating neuronal plasticity because of their key contribution in determining the threshold for action potential generation (for review, see Cantrell and Catterall 2001).

$\mathrm{A} \mathrm{Na}^{+}$-dependent reduction in the ability of B51 to fire might occur, for example, through altering the functional kinetics of VG $\mathrm{Na}^{+}$channels (Srinivasan et al. 1998; for review, see Yu and 
Catterall 2003). $\alpha$-Subunits of B51 VG Na${ }^{+}$channels are a likely target of modulation by LTS training. The positively charged lysine and arginine residues on the S4 segment of the $\alpha$ subunit are key regulators of voltage sensing (Yu and Catterall 2003), and, subsequently, of activation kinetics in many vertebrate and invertebrate species, including Aplysia (Vassilev et al. 1988; Catterall 1995, 2014; Dyer et al. 1997; Ruiz and Kraus 2015). Mutation of arginine residues in the S4 segment reduces the steepness of $\mathrm{Na}^{+}$voltage-dependent gating (Stühmer et al. 1989; Kontis et al. 1997), with a subsequent greater depolarization required to activate $\mathrm{VG} \mathrm{Na}{ }^{+}$channels. When arginines are replaced by cysteines in the $\mathrm{S} 4$ segment of $\mathrm{VG} \mathrm{Na}{ }^{+}$channels, segment movement needed to achieve full activation and influx of $\mathrm{Na}^{+}$during depolarization is suppressed (Yang et al. 1996). Therefore, learning-induced modulation of positively charged residues of the $\mathrm{S} 4$ segment of $\mathrm{VG} \mathrm{Na}^{+}$channels might underlie B51 decreased excitability after training.

Learning-dependent modulation of $\mathrm{Na}^{+}$channels has been previously reported in the pond snail Lymnaea stagnalis. Changes in currents at the level of the tonically firing cerebral giant cells (CGCs), which play a permissive role in feeding (Straub and Benjamin 2001), altered the activity of command-like interneurons in the feeding neural circuit (Kemenes et al. 2006). Specifically, one-trial chemical classical conditioning induces a depolarization of CGCs via a persistent $\mathrm{Na}^{+}$current that appears involved in the maintenance of the long-term memory (Kemenes et al. 2006; Nikitin et al. 2008).

The diversity in the type of $\mathrm{Na}^{+}$channel modulated by learning paradigms in CGCs and B51 is consistent with the different behaviors of these two neurons and the induced cellular correlates. In CGC, a change in persistent $\mathrm{Na}^{+}$channels leads to modifications of the membrane potential (an increase, in the case of appetitive classical conditioning) that modulate its output to CPG neurons, without altering other CGC properties, including excitability and firing frequency (Kemenes et al. 2006). In B51, a change in $\mathrm{VG} \mathrm{Na}{ }^{+}$channels leads to modification of the firing threshold (an increase in the case of sensitization training) that represents an effective mechanism to control the neuron's excitability and, subsequently, the all-or-nothing expression of the plateau potential.

Further experimentation is required to investigate the mechanisms underlying the above modulation of $\mathrm{VG} \mathrm{Na}^{+}$channels induced by sensitization training and its functional relevance in the feeding suppression induced by sensitization training. For example, the biochemical pathway responsible for feeding suppression and the $\mathrm{Na}^{+}$-dependent B51 decreased excitability is yet unknown. Despite its well-established modulatory role in sensitization in Aplysia (Byrne and Hawkins 2015), serotonin does not alter feeding or B51 excitability (Shields-Johnson et al. 2013). Dopamine leads to an increase, rather than a decrease of B51 excitability through a cAMP-dependent mechanism when it is released contingently with B51 activity during operant reward learning in Aplysia (Brembs et al. 2002; Lorenzetti et al. 2008). A putative modulator responsible for the $\mathrm{Na}^{+}$-dependent decrease of $\mathrm{B} 51 \mathrm{ex}$ citability is nitric oxide, which mediates nociceptive sensitization in Aplysia (Lewin and Walters 1999) and plasticity of VG $\mathrm{Na}^{+}$ channels in vertebrate neurons (for review, see Ahern et al. 2015).

\section{Acknowledgments}

This research was funded by NSF grant IOS-1120304 (R.M.), Texas Research Development Grant 140130-10090 (R.M. and M.L.W.) and by the Graduate Summer Research Development Program (J.S.H.). We thank Max Odem, Zachary Jones, Tammy Flores, Harris Weisz, Elizabeth Hager, Valerie Miranda for their research aid and many hours of animal training.

\section{References}

Acheampong A, Kelly K, Shields-Johnson M, Hajovsky J, Wainwright M, Mozzachiodi R. 2012. Rapid and persistent suppression of feeding behavior induced by sensitization training in Aplysia. Learn Mem 19: 159-163.

Ahern CA, Payandeh J, Bosmans F, Chanda B. 2015. The Hitchhiker's guide to the voltage-gated sodium channel galaxy. J Gen Phys 147: 1-24.

Alkon DL, Sakakibara M, Forman R, Harrigan J, Lederhendler I, Farley J. 1985. Reduction of two voltage-dependent $\mathrm{K}^{+}$currents mediates retention of a learned association. Behav Neural Biol 44: 278-300.

Ardiel EL, Rankin CH. 2010. An elegant mind: learning and memory in Caenorhabditis elegans. Learn Mem 17: 191-201.

Brembs B, Lorenzetti FD, Reyes F, Baxter DA, Byrne JH. 2002. Operant reward learning in Aplysia: neuronal correlates and mechanisms. Science 296: $1706-1709$.

Brons J, Woody C. 1980. Long-term changes in excitability of cortical neurons after Pavlovian conditioning and extinction. J Neurophysiol 44: 605-615.

Brunelli M, Garcia-Gil M, Mozzachiodi R, Scuri R, Zaccardi ML. 1997. Neurobiological principles of learning and memory. Arch Ital Biol 135: $15-36$.

Byrne JH, Hawkins RD. 2015. Nonassociative learning in invertebrates. Cold Spring Harb Prespect Biol 7: 021675.

Cantrell AR, Catterall WA. 2001. Neuromodulation of $\mathrm{Na}^{+}$channels: an unexpected form of cellular plastiticity. Nat Rev Neurosci 2: 397-407.

Catterall WA. 1995. Structure and function of voltage-gated ion channels. Ann Rev Biochem 64: 493-531.

Catterall WA. 2014. Structure and function of voltage-gated sodium channels at atomic resolution. Exp Physiol 99: 35-51.

Chen HM, Baxter D, Byrne JH. 2012. Voltage-clamp analysis of identified neuron B51 in Aplysia Program \# 294.04 Neuroscience 2012 Abstracts. Society for Neuroscience, New Orleans, LA, Online.

Cleary LJ, Byrne JH, Frost WN. 1995. Role of interneurons in defensive withdrawal relaxes in Aplysia. Learn Mem 2: 133-151.

Cleary L, Lee WL, Byrne JH. 1998. Cellular correlates of long-term sensitization in Aplysia. J Neurosci 15: 5988-5998.

Crow TJ, Alkon DL. 1980. Associative behavioral modification in Hermissenda: cellular correlates. Science 209: 412-414.

Dickinson KJ, Wainwright ML, Mozzachiodi R. 2015. Change in excitability of a putative decision-making neuron in Aplysia serves as a mechanism in the decision to not feed following food satiation. Behav Brain Res 15: $131-136$.

Dong Y, Green T, Saal D, Marie H, Neve R, Nestler E, Malenka R. 2006. CREB modulates excitability of nucleus accumbens neurons. Nat Neurosci 9: $475-477$.

Dyer J, Johnston WL, Castellucci VF, Dunn RJ. 1997. Cloning and tissue distribution of the Aplysia $\mathrm{Na}^{+}$channel $\alpha$-subunit cDNA. DNA Cell Biol 16: $347-356$.

Farley J. 1988. Associative training results in persistent reductions in a calcium-activated potassium current in Hermissenda type B photoreceptors. Behav Neurosci 102: 784-802.

Frost W, Castellucci V, Hawkins R, Kandel E. 1985. Monosynaptic connections made by the sensory neurons of the gill- and siphon-withdrawal reflex in Aplysia participate in the storage of long-term memory for sensitization. Proc Natl Acad Sci 82: 8266-8269.

Gilly WF, Gillette R, McFarlane M. 1997. Fast and slow activation kinetics of voltage-gated sodium channels in molluscan neurons. J Neurophysiol 77: $2373-2384$.

Herdegen S, Conte C, Kamal S, Calin-Jageman R, Calin-Jageman I. 2014. Immediate and persistet transcriptional correlates of long-term sensitization training at different CNS loci in Aplysia californica. PLoS One 12: 1-21.

Hurwitz I, Ophir A, Korngreen A, Koester J, Susswein AJ. 2008. Currents contributing to decision making in neurons B31/B32 of Aplysia.J Neurophysiol 99: 814-830.

Jacklet J, Tieman D. 2004. Nitric oxide and histamine induce neuronal excitability by locking background currents in neuron MCC of Aplysia.J Neurophysiol 91: 656-665.

Jacklet J, Grizzaffi J, Tieman D. 2006. Serotonin and cAMP induce excitatory modulation of a serotonergic neuron. J Neurobiol 66: 499-510.

Johansen J, Cain C, Ostroff L, LeDoux J. 2011. Molecular mechanisms of fear learning and memory. Cell 147: 509-524.

Kandel ER. 2001. The molecular biology of memory storage: a dialogue between genes and synapses. Science 294: 1030-1038.

Kemenes I, Staub VA, Nikitin ES, Staras K, O'Shea M, Kemenes G, Benjain PR. 2006. Role of delayed nonsynaptic neuronal plasticity in long-term associative memory. Curr Biol 16: 1269-1279.

Kim CS, Change PY, Johnston D. 2012. Enhancement of dorsal hippocampal activity by knockdown of HCN1 channels leads to anxiolytic- and antidepressant-like behaviors. Neuron 75: 503-516. 
Kontis KJ, Rounaghi A, Goldin AL. 1997. Sodium channel activation gating is affected by substitutions of voltage sensor positive charges in all four domains. J Gen Physiol 110: 391-401.

Kupfermann I. 1974. Feeding behavior in Aplysia: a simple system for the study of motivation. Behav Biol 10: 1-26.

Lambertsen KL, Gramsbergen JB, Sivasaravanaparan M, Ditzel N, Sevelsted-Møller LM, Oliván-Viguera A, Rabjerg M, Wulff H, Köhler R. 2012. Genetic Kca3.1-deficiency produces locomotor hyperactivity and alterations in cerebral monoamine levels. PLoS One 7: 1-15.

LeDoux J. 2012. Rethinking the emotional brain. Neuron 73: 653-677.

Lewin MR, Walters ET. 1999. Cyclic GMP pathway is critical for inducing long-term sensitization of nociceptive sensory neurons. Nat Neurosci. 2: $18-23$.

Lewis AS, Vaidya SP, Blaiss CA, Liu Z, Stoub TR, Brager DH, Chen X, Bender RA, Estep CM, Popov AB, et al. 2011. Deletion of the hyperpolarization-activated cyclic nucleotide-gated channel auxiliary subunit TRIP8b impairs hippocampal Ih localization and function and promotes antidepressant behavior in mice. J Neurosci 20: 7424-7440.

Lorenzetti FD, Mozzachiodi R, Baxter DA, Byrne JH. 2006. Classical and operant conditioning differentially modify the intrinsic properties of an identified neuron. Nat Neurosci 9: 17-19.

Lorenzetti FD, Baxter DA, Byrne JH. 2008. Molecular mechanisms underlying a cellular analog of operant reward learning. Neuron 59: 815-828.

Lovell PV, Carleton JB, Mello CV. 2013. Genomics analysis of potassium channel genes in songbirds reveals molecular specializations of brain circuits for the maintenance and production of learned vocalizations. BMC Genomics 14: 470 .

Mason MJ, Watkins AJ, Wakabayashi J, Buechler J, Pepino C, Brown M, Wright WG. 2014. Connecting model species to nature: predator-induced long-term sensitization in Aplysia californica. Learn Mem 21: 363-367.

Mirkovic K, Palmersheim J, Lesage F, Wickman K. 2012. Behavioral characterization of mice lacking Trek channels. Front Behav Neurosci 6: $1-9$.

Mozzachiodi R, Byrne JH. 2010. More than synaptic plasticity: role of nonsynaptic plasticity in learning and memory. Trends Neurosci 33: $17-26$.

Mozzachiodi R, Lorenzetti FD, Baxter DA, Byrne JH. 2008. Changes in neuronal excitability serve as a mechanism of long-term memory for operant conditioning. Nat Neurosci 11: 1146-1148.

Nargeot R, Simmers J. 2012. Functional organization and adaptability of a decision-making network in Aplysia. Front Neurosci 6: 113.

Nargeot R, Baxter DA, Byrne JH. 1999a. In vitro analog of operant conditioning in Aplysia. I. Contingent reinforcement modifies the functional dynamics of an identified neuron. J Neurosci 19: 2247-2260.

Nargeot R, Baxter DA, Byrne JH. 1999b. In vitro analog of operant conditioning in Aplysia. II Modifications of the functional dynamics of an identified neuron contribute to motor pattern selection. J Neurosci 19: $2261-2272$.

Nikitin ES, Kiss T, Staras K, O'Shea M, Benjamin PR, Kemenes G. 2008. Persistent sodium current is a target of cAMP-Induced neuronal plasticity in a state-setting modulatory interneuron. J Neurophysiol 95: $453-463$.

Plummer M, Kirk M. 1990. Premotor neurons B51 and B52 in the buccal ganglia of Aplysia californica: synaptic connections, effects of ongoing motor rhythms, and peptide modulation. J Neurophysiol 63: 539-558.
Remage-Healey L, Dong S, Maidment N, Schlinger B. 2011. Presynaptic control of rapid estrogen fluctuations in the songbird auditory forebrain. J Neurosci 31: 10034-10038.

Ruiz M, Kraus R. 2015. Voltage-gated sodium channels: structure, function, pharmacology and clinical indications. J Med Chem 58: 7093-7118.

Schall JD. 2003. Neural correlates of decision processes: neural and mental chronometry. Curr Opin Neurobiol 13: 182-186.

Scholz KP, Byrne JH. 1987. Long-term sensitization in Aplysia: biophysical correlates in tail sensory neurons. Science 235: 685-687.

Shields-Johnson M, Hernandez J, Torno C, Adams K, Wainwright M, Mozzachiodi R. 2013. Effects of sensitizing stimuli beyond defensive circuits in Aplysia: reduced excitability in an identified neuron critical for feeding. Learn Mem 20: 1-5.

Srinivasan J, Schachner M, Caterall WA. 1998. Interaction of voltage-gated sodium channels with the extracellular matrix molecules tenascin-C and tenascin-R. Proc Natl Acad Sci 95: 15753-15757.

Staras K, Gyóri J, Kemenes G. 2002. Voltage-gated ionic currents in an identified modulatory cell type controlling molluscan feeding. Eur $J$ Neurosci 15: 109-119.

Straub VA, Benjamin PR. 2001. Extrinsic modulation and motor pattern generation in a feeding network: a cellular study. J Neurosci 21: $1767-1778$.

Stühmer W, Conti F, Suzuki H, Wang X, Noda M, Yahadi N, Kubo H, Numa S. 1989. Structural parts involved in activation and inactivation of the sodium channel. Nature 339: 597-603.

Susswein AJ, Kupfermann I, Weiss KR. 1976. The stimulus control of biting in Aplysia. J Comp Physiol [A] 108: 75-96.

Tomchik SM, David RL. 2009. Dynamics of learning-related cAMP signaling and stimulus integration in the Drosophila olfactory pathway. Neuron 64: 510-521.

Truchet B, Manrique C, Sreng L, Chailian FA, Roman FS, Mourre C. 2012. Kv4 potassium channels modulate hippocampal EPSP-spike potentiation and spatial memory in rats. Learn Mem 19: 282-293.

Trudeau LE, Baux G, Fossier P, Tauc L. 1993. Transmitter release and calcium currents at an Aplysia buccal ganglion synapse I. Characterization. Neurosci 53: 571-580.

Vassilev P, Scheuer T, Catterall WA. 1988. Identification of an intracellular peptide segment involved in sodium channel inactivation. Science 241: 1658-1661.

Wainwright M, Zhang H, Byrne JH, Cleary L. 2002. Localized neuronal outgrowth induced by long-term sensitization training in Aplysia. J Neurosci 22: 4132-4141.

Watkins AJ, Goldstein DA, Lee LC, Pepino CJ, Tillett SL, Ross FE, Wilder EM, Zachary VA, Wright WG. 2010. Lobster attack induces sensitization in the sea hare, Aplysia californica. J Neurosci 30: 11028-11021.

Weiss KR, Shapiro E, Kupfermann I. 1986. Modulatory synaptic actions of an identified histaminergic neuron on the serotonergic metacerebral cell of Aplysia. J Neurosci 8: 2393-2402.

Yang N, George A, Horn R. 1996. Molecular basis of charge movement in voltage-gated sodium channels. Neuron. 16: 113-122.

Yu FH, Catterall WA. 2003. Overview of the voltage-gated sodium channel family. Genome Biol 4: 207.

Zhang W, Linden D. 2003. The other side of the engram: experience-driven change in neuronal intrinsic excitability. Nat Rev Neurosci 11: 885-900.

Received December 18, 2016; accepted in revised form March 31, 2017. 

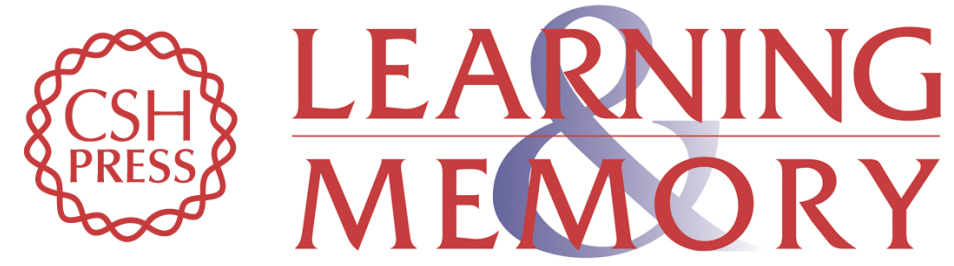

\section{Long-term sensitization training in Aplysia decreases the excitability of a decision-making neuron through a sodium-dependent mechanism}

John S. Hernandez, Marcy L. Wainwright and Riccardo Mozzachiodi

Learn. Mem. 2017, 24:

Access the most recent version at doi:10.1101/lm.044883.116

\section{Supplemental http://learnmem.cshlp.org/content/suppl/2017/05/09/24.6.257.DC1 \\ Material}

References This article cites 66 articles, 19 of which can be accessed free at: http://learnmem.cshlp.org/content/24/6/257.full.html\#ref-list-1

Creative This article is distributed exclusively by Cold Spring Harbor Laboratory Press for the Commons first 12 months after the full-issue publication date (see License http://learnmem.cshlp.org/site/misc/terms.xhtml). After 12 months, it is available under a Creative Commons License (Attribution-NonCommercial 4.0 International), as described at http://creativecommons.org/licenses/by-nc/4.0/.

Email Alerting Receive free email alerts when new articles cite this article - sign up in the box at the Service top right corner of the article or click here. 